\title{
French Grammatical Accents: Practices, Sociolinguistic Foundations, and Pedagogical Implications in a Multilingual Setting
}

\author{
Antoine Willy Ndzotom Mbakop \\ University of Maroua
}

\begin{abstract}
Correspondence concerning this article should be addressed to Antoine Willy NDZOTOM MBAKOP, BP 46, Maroua, Far North Region, Cameroon.E-mail: awnmbakop@gmail.com
\end{abstract}

\section{Sonia Laurel Emalieu Kanko \\ University of Maroua}

\begin{abstract}
Correspondence concerning this article should be addressed to Sonia Laurel EMALIEU KANKO, the Higher Teachers' Training College, Department of Bilingual Letters BP 46, University of Maroua , Maroua, Far North Region, Cameroon. E-mail: kankosonia@yahoo.com
\end{abstract}

\section{Michelle Adrienne Tida \\ University of Maroua}

\begin{abstract}
Correspondence concerning this article should be addressed to Michelle Adrienne TIDA, the Higher Teachers' Training College, Department of Bilingual Letters, University of Maroua, BP 46, Maroua, Far North Region, Cameroon.E-mail: timiad23@gmail.com
\end{abstract}

\begin{abstract}
The present paper probes the use of French grammatical accents by English-speaking learners of French in a multilingual country: Cameroon. Its aim is twofold. First, it highlights the extent to which the various appropriative uses of French by French-speaking Cameroonians influence the form of the language spoken by their English-speaking counterparts. Then, it checks the effect of the language spoken by these learners on their written language. The data were collected among 160 Form 3 and Form 4 pupils from two high schools in the town of Maroua, Far North Region, Cameroon. Six tests and fifty tape recordings were carried out among the target population. Also, four French teachers were tape recorded during the exercise. The analysis of the errors made by the informants revealed significant patterns of acute and grave accents in the spoken language of respondents. These patterns of oral usage were found to strongly correlate with their written production. It therefore appears that Cameroon French displays some specific phonological characteristics, which severely spoils the acquisition of grammatical accents by English-speaking Cameroonians. These findings may revive the debate over whether French in former colonies should adapt to its contexts or keep its native purity.
\end{abstract}

Keywords: grammatical accents, multilingualism, second language acquisition, French, Cameroon, language teaching

Although Cameroon is, by its Constitution, an officially French-English Bilingual country, space dynamics reveal the overwhelming importance of French. In fact, the language is spoken in $4 / 5$ of the territory, while English is spoken in 1/5. French is the dominant official language in Cameroon. It is the major language in the administration, the army, and most official spheres in the country. In addition to French and English, there are about 300 indigenous languages shared among six to eight ethnic groups (Lewis, 2009; Kouega , 2007; Altapedia online, 2003; Grimes, 2000; Ngoh, 1987; Dieu \& R. Renaud, 1983). The French-English distribution was based on the Mandate granted to France and England by the League 
of Nations, following the Treaty of Versailles that marked the defeat of Germany in World War I (Mendo $\mathrm{Ze}, 1992)$. Another aspect of its Constitution is that the two official languages have no territorial right, although the Francophone/Anglophone dichotomy is very strongly felt. This distinction is felt even more in the educational system where two sub-systems of education co-occur at nursery, primary, and secondary level.

In a context where French is numerically, and even politically and socially the dominant language, major human agglomerations are French-inclined. Unfortunately, the language, through its various statuses in the country, namely first, second, official, and foreign language, has undergone several appropriative uses in Cameroon. These uses are determined by a few interferences, which sometimes result in impressive lexico-semantic and stylistic creativity by its speakers. These interferences were investigated by Wamba \& Noumssi (2003), who probed four regional accents of French, as well as a few creative processes in the uses of the language. The four regional accents were the Bamileke, the Northern, the Centre/South, and the Littoral accents. In the Bamileke accent, back sounds tend to be replaced by front ones for functional reasons. In that vein, Bamileke speakers usually fail to pronounce $/ \mathrm{s} /$ in final positions as in the excerpt 'Il n'est pas mon frère'

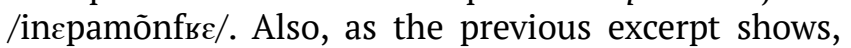
when the phonemes $/ 1 /, / \mathrm{r} /$, and $/ \mathrm{n} /$ occur in implosive situations, they are not clearly pronounced or are simply not pronounced. The Centre/South accent is marked, among other things, by a slow and melodic intonation where consonants that precede the vowel ' $o$ ' tend to be labialised. The Northern accent has a characteristic lengthening of the phoneme $/ \mathrm{r}$ /, while the Littoral accent, especially the Basaa trend displays the difficulty to pronounce such vowel sounds as $/ y /$, $/ \mathrm{o} /, / œ /$, and $/ \varnothing /$ which are not found in that language. The creative processes included collocational change, denotational modification, and translation (Fosso, 1999). In the case of collocational change, a lexeme is inserted in an environment where it does not naturally collocate to build a new meaning. An expression like 'à la sueur de son front' [to work hard and sweat] is turned into 'à la sueur de son sexe' [to earn something through sex] where 'sexe' does not collocate with 'sueur'. In denotational modification, the denotational meaning of a lexeme is replaced by another one, so that a verb like 'assurer', literally meaning the ability to carry out one's duty as expected, is changed into having sex with a woman. Translation is used here to refer to a metaphorical or metonymic naming of things (the woman vagina is referred to as la forêt [the forest] for example. Each accent is peculiar regarding specific sounds in the language, and underscores the fact that the French phonetic system differs quite significantly from that of most Cameroonian languages (Mendo Ze, 1992; Zang Zang, 1999). The problems faced by Cameroonians are not limited to phonology. (Onguene Essono, 2012) showed that the use of prepositions by some journalists revealed the influence of their mother tongue, although some of the errors made could not be traced to any Cameroonian language. A key aspect of this misuse of prepositions is the overgeneralization of à, which, to the author, is coherent with the structure of many local languages that usually do not have more than four prepositions (especially Bantu languages). The above-mentioned examples have raised the dangerous effects of these deviant uses, while others have championed the benefits of the appropriative use of the language. In that vein, Nzesse, in 2008, had this to say:

Normalement, pour que le français langue d'origine étrangère, devienne fonctionnellement la langue du camerounais dans la praxis quotidienne, il faut bien qu'il l'adapte à sa culture, à l'environnement qu'il côtoie, c'està-dire qu'il finisse par se donner une variété vernaculaire, sorte d'interlangue grâce à laquelle il peut communiquer avec les autres, se reconnaître et se particulariser. (p.308)

[Normally, before Cameroonians can functionally use French, a foreign language, in their daily practices, they must adapt it to the culture, the environment around them; that is, they should eventually create a local variety, a sort of interlanguage through which they can communicate with others, self-identify, and particularize]

To Manessy (1979), French in Africa appears as a continuum with one extreme featuring the "very pure language' (p. 93) used by many writers and intellectuals, and another one where the language can hardly be traced to the original French that fathered it. This can be explained by the fact that linguistic features can serve to distinguish social, racial, and language groups (Labov, 1966; Trudgill, 1974). Unfortunately, although errors made by French-speaking Cameroonians in the use of French have been highly investigated, no researcher seems to have ventured, to the best of our knowledge, into the area of investigating errors made by English-speaking Cameroonians in the use of French, especially from the perspective of the influence of Cameroonian French on the written production of this population. This gap owes a lot to a number of factors. First, French is theoretically one of the languages that requires the least number of instructional hours in order for an English speaker to reach a high level of speaking proficiency; the Defense Language Institute Foreign Language Center regards French as a Category 1 language in that respect (Bullock, 2009). Next, the putative problems French can pose to an English-speaking learner seem to be obvious enough to Cameroonians, some of 
which include phonological variations between the languages of some phonemes, grammatical variations in terms of verbal structure, and lexical gaps, just to name a few. Bullock, for example, lists some French sounds that English speakers usually fail to pronounce well, including /y/. An English speaker will also have problems with French gender, as French proceeds quite differently from English (Vinay and Darbelnet, 1977). This awareness of differences and similarities between French and English is the consequence of habit, as well as some language awareness developed through Contrastive Studies of English and French in most State universities through such coursebooks as Stylistique comparée du français et de l'anglais by Vinay and Darbelnet (1977). This course book is studied in Cameroon at the undergraduate level in the Bilingual Studies Department in most state universities. It is a stylistic comparison of French and English, which covers general differences and similarities between French and English. Many other works have underscored the differences and similarities between English and French, as well as the implications of such differences and similarities on the acquisition on the other language. Studies of the acquisition of the postverbal location of L2 French manner and frequency adverbs by L1 English-speaking learners (White, 1989), the structure of English and French clauses (Pollock, 1989), and the acquisition of French verb movement by native speakers of English (Hawkins, Towell, \& Bazergui, 1993) are a few illustrations of the interest in the use of French by English speakers. The case of Cameroon requires a different perspective on the issue. Most works along these lines were carried out in Canada, a French-English bilingual country like Cameroon. Unlike Cameroon, English-speaking Canadian learners of L2 French are usually exposed to a specific variety of French, which, although it differs slightly from the Parisian variety, differs greatly from the variety spoken in Africa, as shown by Cameroonian researchers. For example in Cameroon, the Englishspeaking Cameroonian has a local language as his or her mother tongue, Pidgin-English as a vehicular language, and then English. The French he or she is exposed to comes from people who do not have French as a mother tongue and for whom several appropriative uses have evolved that have 'polluted' the original language. In fact, after WWI, France took possession of one part of Cameroon where French became the main language. However, as Wamba \& Noumssi (2003), Onguene Essono (2012), and Mendo Ze (1992) have demonstrated, Francophone Cameroonians have evolved a local brew of French. Given that the main contact Anglophone Cameroonians have with French is through their Francophone counterparts (either via direct contact or through teaching, French teachers either having been trained by Francophones or being themselves Francophones), they learn or acquire a form which is not like the original (polluted). Therefore, in the process of acquiring L2 French, the learners' upheavals are doubled, mainly because of incorrect exposure both on the playground and even during French classes.

Two approaches to the analysis of errors faced by second and foreign language learners have generally been adopted, namely contrastive analysis and error analysis. Error analysis emerged in reaction to the shortcomings of contrastive analysis, and intends to study the problems faced by second language learners as 'errors' whose origins are not only found in the source language of the learners, but also in their target language (Gass \& Selinker, 2008). Studies in error analysis usually group the sources of errors into three broad categories, namely interlingual, intralingual (Gass \& Selinker), and teaching-induced errors (Filipovic, 1972). Interlingual factors mean errors in a learner's performance that can be attributed directly to interference from his or her mother tongue (Selinker, 1972). This has been the main cause of errors made by Francophone learners of French in Cameroon, as highlighted above. According to Tarone $(1969,1979)$, interlingual factors lead to three types of transfer: negative, positive, and divergent negative transfers. With negative transfer, the learner uses inappropriate sound patterns and other elements from his or her mother tongue in place of the target language model. There is positive transfer when no difficulty is displayed by the learner. Divergent negative transfer occurs when the learner perceives the target language element as the most difficult. Generally, interlingual factors have usually been blamed on the mother tongue. In that respect, several scholars have recognized the impact of the mother tongue on the acquisition of a second language (Lado, 1957; Ferguson, 1975; Selinker). Intralingual factors, on the other hand, are usually 'developmental' since they are related to the L2. They are usually broken down into overgeneralization, ignorance of rule restrictions, incomplete application of rules, and false concept hypothesis (James, 1998; Scovel, 2001). Teaching-induced errors have been acknowledged by Corder (1974) and Filipovic. These errors are usually attributed to 'bad teaching' or 'incorrect exposure'. In that vein, the problems faced by students are usually believed to be due to the fact that they are more in contact with poor models than good models of English.

The present paper builds on the incorrect exposure perspective, from the postulate that errors can start in one group (first generation) and then spill over to a second (second generation) through contact. In first generation errors, the difficulties faced by the learner are directly associated with either the L2 or the L1 of the learners, where the L2 maintains all of the original 
properties. This is the case when an Anglophone learner of French as a second language has problems with French pronunciation $(/ \mathrm{y} /$ for example is a major challenge to those learners), verbal complements, gender, etc. (Onguene Essono, 2012; Bullock, 2009; Nzesse, 2008; Wamba \& Noumssi, 2003) The problem lies in the intrinsic nature of French, as opposed to English, which is their first language. In fact, with intralingual factors, the learner is still the initial cause, since there is no mediator between the learner and the problem he or she faces. However, when the problem the learner faces is neither of his or her direct making, nor that of the language, one can rightfully speak of a second-generation source. In fact, if the language $\mathrm{s} / \mathrm{he}$ is exposed to has already been perverted by a first generation of users (in this case Francophone Cameroonians who speak or teach French with or to their Anglophone counterparts), the problem becomes more complex since solving it would require solving language problems faced by Francophones first. The work assumes that the various appropriative uses of French by Francophone Cameroonians hamper the acquisition of the language by their Anglophone counterparts. These learners of French do not have a native model to begin with, French being their second official language and a de facto foreign language for most of them. They are exposed to an already "polluted" version of the language, a second-level pollution that adds to the very difficulties learners of a foreign language are faced with such as overgeneralization, poor implementation of the rules, etc. This study therefore hypothesised that the oral form of the language spoken around the learners, and which they reproduce in their daily communication, influences their written production. This position is established in relation with grammatical accents. These accents are believed to influence the spelling of words they belong to. In fact, consonant doubling is often influenced by the "accentedness" or not of a letter, especially " $\mathrm{e}$ ", which, when accented or not determines the doubling or not of the following consonant. Thus, this work intends to establish that appropriate pronunciation can be associated with proper writing, at least to some extent. The difficulty to cope with this aspect of French may stem from the fact that the grave and the acute accents display very complex features in their usage. The present paper therefore aims to probe the effects of the pronunciation of French grammatical accents on the written performance of Anglophone learners of French as a second language in Cameroon.

\section{Materials and Methods}

The data for this investigation were collected and analysed following Corder (1975), with a focus on errors induced by incorrect exposure. In a typical Corder's (1975) model, the first step is the description of learners' errors. Next, the errors are classified, and finally the sources and causes of the errors are examined. This study follows a similar pattern. First, the errors are identified and classified into patterns; finally the sources and causes of the errors are discussed.

\section{Participants}

In all, 160 secondary school students and four French teachers were case-studied in this research paper; 95 Form III and 65 Form IV students from the only two schools that offered an Anglophone subsystem of education in the town of Maroua, namely The Government Bilingual High School Maroua and Jacques de Bernon Bilingual College Maroua. The choice of these students was not fortuitous. In fact, after Form 4, students get into more specialised classes where very few continue to take French lessons. The four teachers were in charge of the classes in both schools (so their students were used to them), two at Government Biilingual High School Maroua and two at Jacques de Bernon Bilingual College Maroua, respectively. However, although all 160 students took the written test, only 45 took part in the oral evaluation, given its difficulty and time constraints.

\section{Materials}

The instruments were a test, a tape recorder, and participant observation. The test was actually a two-stage dictation comprising four different texts (see Appendix). Each text was devised to display the different accent variations for each of the four patterns identified for the verbal forms involved with the grave and acute accents on the "e" grapheme. The dictations were tape-recorded to describe the teachers' handling of the accents in a bid to sort out possible mistakes they made and the effect this could have on their learners. Two other texts were submitted to the learners for reading. The reading was read aloud and tape-recorded. The researchers took part in all the testing operations through participant observation, sitting at the back of the class with the tape recorder.

\section{Administration}

In each of the four classes selected for the investigation, the students underwent two different dictations, one by their French teacher and another by a "model reader" (the researcher). The dictation was carried out as follows: the text read once for acquaintance, a second time for writing, and a third 
time for verification. The tape recording took place after the class with 45 students over four days, with many being reluctant to undergo the second phase. They were asked to read the two texts they were subjected to, and their production was recorded for analysis. The teacher's dictation was tape-recorded as well.

\section{Measures}

The error count was the most difficult part of the endeavor. For each test, one item was chosen to represent one pattern, and all the informants were evaluated on that item. This means that for each pattern, good performance referred to the number of respondents who provided the correct spelling. The oral production was measured against the International Phonetic Alphabet recommendations. The respondents' productions were therefore transcribed as heard. The analysis of the data involved identifying the errors made by the learners and the teachers. Next, the source of the errors made by the learners was sorted in connection with the language they were exposed to through their teachers. Although the focus was not the first language of the learners, its effect was also examined.

\section{Results and Discussion}

This section deals with the patterns of grammatical accents in French as classified for the purpose of this study. Next the learners' oral and written performance and the sources of errors are considered. Finally, the sociolinguistic and pedagogical implications of the endeavour are discussed.

\section{Patterns of variations of grammatical accents in French}

French grammatical accents include the acute accent (accent aigu), the grave accent (accent grave), and the circumflex (accent circonflexe) (Grevisse \& Goose, 2011). These accentuation marks are referred to as grammatical accents in that they discriminate among otherwise similar words. They also contribute to the "grammaticality" of conjugation.

The placement of grammatical accents is a major area of difficulty in French, both to Francophone and Anglophone Cameroonians. The number of rules that govern this placement is huge and unstable. In addition, the oral rendition of some of them can vary significantly. The absence of an accent can sometimes be very difficult to anticipate. However, in Cameroon French, data have shown the tendency for some local accents of French to distort the rules of pronunciation in one way or another. One, which may be pertinent in this regard, is the difficulty for most Cameroonians, and not just Bamileke, to use the schwa in certain areas. Wamba and Noumssi (2003) highlighted, for example, the unexpected insertion of a schwa in certain words, especially in final position, after a nasal vowel, even in an environment where one is not expected. Thus, 'Il mange' [He eats] will be rendered as /ilmã3ə/, where the final vowel is not necessary.

In fact, the presence or not of an accent (acute and grave) may be very difficult to predict. Grevisse and Goose lists a few rules that can guide spelling in French as follows:

$1^{\circ}$ Pour les voyelles toniques, l'opposition entre é et è est nette : (...) Il n'y a plus d'exception (...) que pour certaines formes verbales suivies de je (...) $2^{\circ}$ Pour les voyelles atones, où l'opposition phonétique est moins marquée, on a en principe è quand la syllabe suivante est formée d'une consonne et d'un e muet, et é dans le cas contraire (...) $3^{\circ}$ Sauf devant s final, on ne met pas d'accent aigu ou d'accent grave sur un e qui ne termine pas la syllabe graphique (...) $4^{\circ}$ Dans une syllabe ouverte (...) le son [e] s'écrit é et non e.

[ $1^{\circ}$ There is a clear-cut opposition between é and è for strong vowels : (...) Exceptions are limited to a few verbal forms followed by je (...) $2^{\circ}$ For weak vowels, where phonetic opposition is less marked, è is obtained in principle when the following syllable is formed by a consonant and a silent e, and é is obtained otherwise (...) $3^{\circ}$ With the exception of a following final S, there is no acute nor grave accent on an e that does not end the graphical syllable (...) $4^{\circ}$ In an open syllable (...) the sound [e] is written é and not e.]

(pp. 109-110)

On the grounds of these rules, along with the numerous exceptions and variations, four patterns of variation of grammatical accents were established in this work, and are discussed in detail below. Note that the list is illustrative, and was established by the authors for the purpose of the present study.

\section{Pattern I}

This pattern comprises nouns and their derivatives in which the grapheme "e" is not accented in the penultimate position because the final syllable is accented, as described in Rule 2 above (Grevisse and Goose). They are actually very few in number and are sampled in Table 1.

Table 1

Pattern I type of accent variation

\begin{tabular}{cc}
\hline \multicolumn{1}{c}{ Word } & Transcription \\
\hline Médecin [Medical doctor] & $/ \mathrm{m} \varepsilon(\mathrm{e}) \mathrm{ds} \tilde{\varepsilon} /$ \\
Pèlerin [Pilgrim] & $/ \mathrm{p} \varepsilon \operatorname{lr} \tilde{\varepsilon} /$ \\
\hline
\end{tabular}


Table 1 shows that the second "e" is silent in all four words, however, they are usually pronounced with an acute accent by Francophone Cameroonians. Their derivatives: Pèlerinage/Médecine.

\section{Pattern II}

Pattern II is made up of verbs whose accentuation varies per tense and person. They usually change from silent in the infinitive to grave or silent (or reduced to /ə/) when inflected (cf. Rule 2, Grevisse \& Goose). Some of those verbs are displayed in Table 2.

Table 2

Pattern II type of accent variation

\begin{tabular}{|c|c|}
\hline Word & Transcription \\
\hline \multirow{3}{*}{ Emmener /ãmne/ } & J'emmène / ãmen/ = $\varepsilon \quad[\mathrm{I}$ bring $]$ \\
\hline & J'emmènerai / ãmenre/ $=\varepsilon$ \\
\hline & J'emmenais / ãmn $\varepsilon /=\varnothing$ \\
\hline \multirow{3}{*}{ Harceler /aьsle/ } & Tu harcèles $/$ авsєl/ $=\varepsilon \quad[$ You harass $]$ \\
\hline & 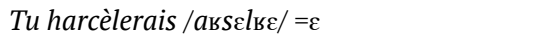 \\
\hline & Tu harcelais $/ / a_{\mathrm{B} s l \varepsilon} /=\varnothing$ \\
\hline \multirow{3}{*}{ Soulever/sulve/ } & Il soulève $/$ sulcv/ $=\varepsilon \quad$ [I lift up] \\
\hline & Il soulèverait $/$ sulevв $/=\varepsilon$ \\
\hline & Il soulevait $/$ sulve $/=\varnothing$ \\
\hline \multirow{3}{*}{ Semer /səme/ } & Je sème /scm/ \\
\hline & Je sèmerais /sєтьв/ \\
\hline & Je semais /səme/ \\
\hline \multirow{3}{*}{ Crever /свәvе/ } & Tu crèves /сьву/ [You starve/You yearn for] \\
\hline & Tu crèverais /сьвvre/ \\
\hline & Tu crevais /kьәvع \\
\hline \multirow{3}{*}{ Enlever } & Il enlève /ãlev/ [He abducts/removes] \\
\hline & Il enlèverait /ãlıvьย/ \\
\hline & Il enlevait /ãlve/ \\
\hline
\end{tabular}

The change from $/ \varnothing /$ to $/ \varepsilon /$ is noticeable, although there is no major orthographical implication. It appears that the accentuation of the grapheme "e" depends on whether the following syllable is accented or not. When it is accented, the grapheme is not, and when it is not accented, the grapheme is accented. This principle also applies to nouns derived from these verbs: enlever [to abduct] takes a penultimate unaccented "e" and an accented final "e", while its derived noun, enlèvement [abduction], reverses the order of accents. The "accentedness" is also useful in

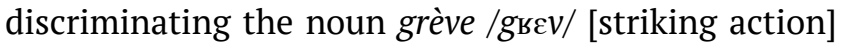
from the verb grever / gкәve/ [to negatively affect], which are wrongly used interchangeably by many Cameroonians to mean "a striking action".

\section{Pattern III}

This pattern is made up of verbs whose infinitives are not accented, but whose conjugated forms display various accents as well as some orthographic changes, namely consonant doubling when the accent is concealed. It is especially the case of verbs with "eter" and "eler" such as: projeter/prozte/[to project], appeler / aple/ [to call], renouveler/вәnuvle/ [to renew] and atteler /atle/ [to hitch up/to couple]. They are recapitulated in Table 3 below.

Table 3

Pattern III type of accent variation

\begin{tabular}{|c|c|}
\hline Word & Transcription \\
\hline \multirow{3}{*}{ Appeler /aple/ } & J'appelle / apel/ \\
\hline & J’appellerai /арєlье/ \\
\hline & J'appelais /aple/ \\
\hline \multirow{3}{*}{ Renouveler /вәпиvle/ } & Tu renouvelles /вәпиvєl/ \\
\hline & Tu renouvelais /вәnuvle/ \\
\hline & Tu renouvellerais /вәпиvєlвє/ \\
\hline \multirow{3}{*}{ Projeter /prozte/ } & Il projette /рвозєt/ \\
\hline & Il projetterait /рьозєtьє/ \\
\hline & Il projetait /pвозtє/ \\
\hline \multirow{3}{*}{ Atteler/atle/ } & Ils attellent /atel/ \\
\hline & Ils attelleraient/atel $l_{\mathrm{ธ} \varepsilon / /}$ \\
\hline & Ils attelaient /atle/ \\
\hline
\end{tabular}

One major feature of this pattern is that the grapheme "e" moves from silent in the infinitive to either silent or $/ \varepsilon /$. Just like the preceding pattern, the absence or presence of the accent is determined by the "accentedness" of the following syllable. But unlike Pattern 2, there is consonant doubling and the accent is always implicit through that doubling.

However, the above-mentioned rules have a few nuances. They are presented below:

1. Nouns derived from these verbs can be included in accent changes. This is the case of the words: appel [a call], projet [a project] that are written with an accent but in oral production are pronounced / apsl, proze /. Nevertheless their verbs are /aple/, /prozte /. For the verb renouveler, its noun form takes the grave accent: renouvèlement/ rənuvelmã / [renewal].

2. The rule stated above does not apply to the verb sceller [to seal]. The infinitive sceller, instead of being pronounced /scle/ is pronounced /sele/, and the conjugated form is /scle/ in all the tenses and persons of conjugation except in the past participle where some changes occur depending on whether it agrees with a masculine or a feminine noun.

Example:

(1) Un seau scellé /ôsosele/ [a sealed bucket]

(2) Une porte scellée /ynportscle/ [a sealed door]

What is very significant here is the fact that the 
accent is never physically present, something that makes sense in a French-English bilingual context like Cameroon. Having two languages with cleardifferences in the use of grammatical accents may be difficult to handle. Anglophone Cameroonians, because of their exposure to English, are not well acquainted with those accents, although they are aware of their existence. In that vein, hearing an accent where one is not physically present can be very troublesome to such learners.

\section{Pattern IV}

Pattern IV is made up of verbs which, in the infinitive, take the acute accent and whose conjugation in some tenses and persons may change the acute accent to the grave one. It is the case with the verbs: pécher/peje/ [to sin], sécher/sese/ [to dry], alléger/aleze/ [to alleviate/lighten], empiéter/ãpiete/ [to encroach on], révéler/sevele/ [to reveal] and aérer/аеке/ [to air] as highlighted in Table 4 below.

Table 4

Pattern IV type of accent variation

\begin{tabular}{|c|c|}
\hline Word & Transcription \\
\hline \multirow{3}{*}{ Pécher /peje/ } & je pèche /pef/ \\
\hline & Je pècherai /pe $\int \mathrm{ธ} \varepsilon /$ \\
\hline & 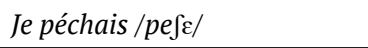 \\
\hline Sécher/seje/ & $\begin{array}{l}\text { Je sèche /s\&f/ } \\
\text { Tu séchais /se } \int \varepsilon /\end{array}$ \\
\hline Lécher /leje/ & $\begin{array}{l}\text { Je lèche /les/ } \\
\text { Tu léchais /lefe/ }\end{array}$ \\
\hline Alléger /aleze/ & 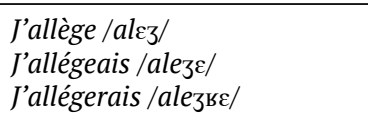 \\
\hline Révéler/веvele/ & 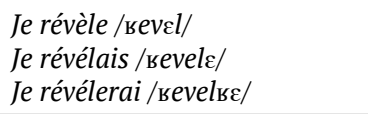 \\
\hline Aérer /аеве/ & 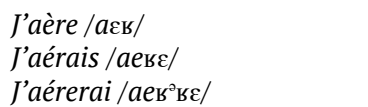 \\
\hline
\end{tabular}

Table 4 above presents a particular point that somehow opposes this pattern to other patterns. Actually, the accent is usually easily identified through pronunciation, and the occurrence of the unaccented $/ \mathrm{o} /$, which seems to be the most troublesome sound throughout this analysis, does not come into play in different variations.

These four patterns of accent variation in connection with the grave and acute accents reveal one major parameter: in the conjugation of verbs, the presence or absence of an accent is very significant, especially to orthography. In fact, the presence of an accent may determine the doubling of the grapheme "l" in some verbs, while the "accentedness" of the penultimate "e" of the root of the verb usually determines the "unaccentedness" of the last grapheme. This has a tremendous didactic implication that doubles with a sociolinguistic one. A good knowledge of these accent variations can contribute to alleviating mental tension on the part of the learner when faced with words involving such structures. However, they are faced with an exposure problem whereby the model they are usually exposed to comes from a speech community where a variety of the language that diverges from the native accent has already evolved.

\section{Learners' performance}

This section discusses the oral and written performance of the learners. The learners' oral performance is discussed first.

\section{Learners' oral performance}

The learners were asked to read one of the six texts used for the collection of the data. Their performance is summarized in Figure 1 below.

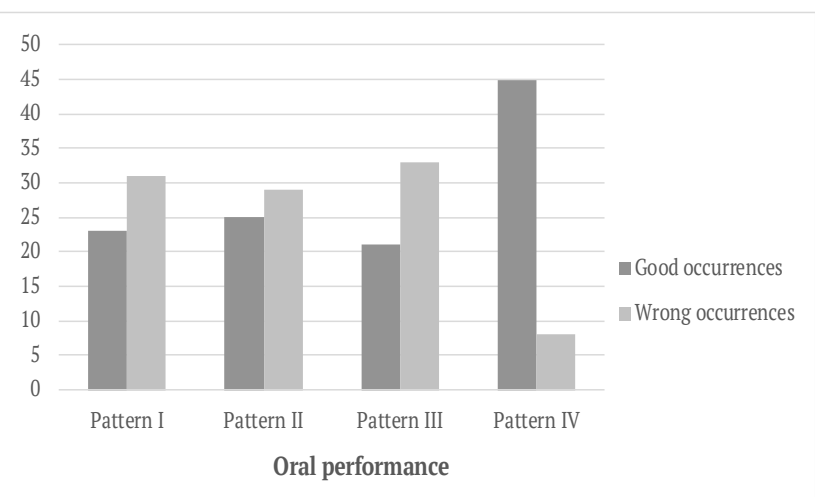

Figure1. Learners' oral performance.

Figure 1 above shows that only Pattern IV seemed easy to the learners. This pattern comprises verbs whose infinitive changes from acute to grave in their finite forms, and displays the least variability. Pattern III appears to be the most complex, probably because of the orthographical change induced by the "accentedness" or not of the preceding "e". Also, the accent did not physically appear, so as to indicate whether an acute or grave accent was required. It was rather the following consonant that was usually doubled. In general, the learners faced some difficulty with this unstable structure of grammatical accents in French. For each pattern, a number of wrong or improper cases were identified. 
Table 5

Major deviant forms identified in association with Pattern I

\begin{tabular}{ccc}
\hline Correct form & $\begin{array}{c}\text { Learners' } \\
\text { pronunciation }\end{array}$ & $\begin{array}{c}\text { Number of } \\
\text { occurrences }\end{array}$ \\
\hline$/$ meds $\tilde{\varepsilon} /$ & /medes $\tilde{\varepsilon} /$ & 26 \\
/pelsina3/ & /pelerina3/ & 19 \\
\hline
\end{tabular}

These forms are congruent with impressionistic observations (/medes $\tilde{\varepsilon} / ; /$ pelerinaz/) among Francophone Cameroonians. Pattern II revealed a high occurrence of /e/ before an accented final "e" grapheme. Such examples were /ãmene/, /suleve/, / sem $\varepsilon /$, and $/ a \int e t \varepsilon /$. This clearly breached the general tendency for the penultimate "e" to be unaccented in French. Similarly, Pattern III underscored the tendency for the informants to pronounce the penultimate "e" with an acute accent in such words as appeler /apele/ and atteler /atele/.

\section{Learners' written performance}

The written performance of the learners, although it contrasted a little with their oral performance, seems to meet our expectations as Figure 2 below shows.

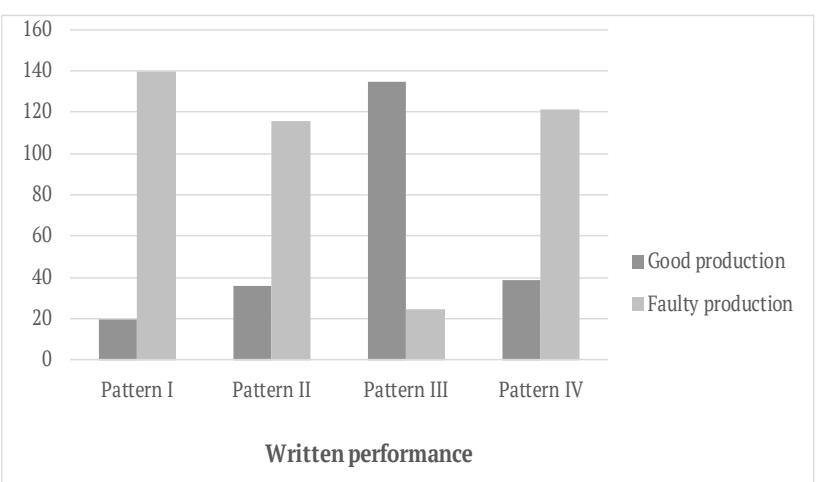

Figure2. Learners' written performance.

In general, as Figure 2 above shows, faulty productions overwhelmingly outdid good or proper production in the written performance of the learners. The difficulties learners faced with Patterns I, II, \& IV can be seen in the variability of the accents involved. However, what is striking is the very high number of good productions in Pattern III. In fact, this is the only pattern with a specific characteristic, namely that of physically featuring no accent. This is due to the fact that once a consonant is doubled the preceding accent is allowed. Perhaps most importantly, the absence of grammatical accents, which doubled with the absence of grammatical accents in their first language, can better decipher this complexity. Actually, it was found that most informants avoided the accent when in doubt. Therefore, it can be intimated that although they could not properly pronounce words using this pattern, they accidentally performed well because of their general penchant for not accenting letters, which in turn is due to the absence of grammatical accents in their first language (English).

The major errors connected with each pattern clearly highlighted the poor mastery of accentuation rules, and the influence of both Cameroonian French and English. The absence of accents in English is shown in the very high frequency of the forms "pelerinage and *medecin in Pattern I, as well as their good performance in Pattern III. All of these revealed important sociolinguistic and pedagogic stakes associated with the use of grammatical accents by Anglophone learners of French in Cameroon.

\section{Sources of errors}

In this section, the errors are globally tackled in terms of interlingual, intralingual, and errors induced by incorrect exposure.

\section{Interlingual errors}

It is difficult to identify any error that could be said to depend on the differences between French and English, although as a general matter grammatical accents in essence constitute an aspect where the two languages sharply differ. However, none of the errors made by the learners could be directly attributed to that difference, mainly because one of the two languages (English) does not feature grammatical accents, except with a few foreign words of French origin. Very contradictorily, English contributed positively (accidentally) to the good performance of the learners in the production of the Pattern III type of accent variation. As Figure 2 shows, 135 good occurrences were found with this pattern, while only 25 wrong occurrences were noted. In fact, this pattern featured no grammatical accent at all. The accent, when it occurred, was concealed by the doubling of the following consonant (appeler/appelle, renouveler/ renouvelle). Given that English does not make use of grammatical accents, learners can be said to have accidentally performed well by leaving out the accent as they usually do when they write English texts. This cannot be called a positive transfer since it is not the result of an existing rule for grammatical accents in English. If one considers that in cases where the accent was not displayed, many learners failed to double the following consonant, then this cannot definitely be called a positive transfer, nor can it be considered an intralingual error.

\section{Intralingual errors}

This category of errors could be said to be the most important in the data collected. In the case of the Pattern I type of accent variation, the major problem was ignorance of rule restrictions. As a general rule, 
accents in French are consistent with both spelling and writing. In that vein, Grevisse \& Goose (2011) point out "l'accent aigu et l'accent grave se mettent sur la lettre e pour indiquer la prononciation: é pour [e], è pour [E]"[the acute accent and the grave accent are placed on the letter $e$ to indicate the pronunciation: é for [e], è for [ع]] (p. 109). However, there are a few cases like médecin where the acute accent is rendered as a grave one. The analysis of the learners' written productions revealed 140 wrong occurrences against 20 good ones. But again, as will be seen later, one can hardly relate this to the rule alone. In Pattern II, the learners seemed to clearly have a poor mastery of the rules, and this can be understood given the complexity of those rules as described above. Although orthographic memory is important too, it appears that they did not only lack knowledge of the rule, but they also overgeneralized the little they thought they knew. The following occurrences underscore the fact that they had very poor knowledge of the words as well as the rules that govern the variations of the grammatical accents with different patterns:

\section{- Emméné \\ - Harcélais \\ - Sémais}

The same can be applied to Pattern IV where they usually mixed up acute and grave accents for such words as allege/allégeais and lèche/léchais. However, as this work intends to show, the main cause of those errors can be traced to the environment of the learners.

\section{Errors induced by incorrect exposure}

This paper hypothesised that the learners were exposed to a low-quality language. More than 'bad teaching', it is 'incorrect exposure' that is highlighted here. In effect, learners' spoken performance is strongly in favour of this stance given that it correlated with their written performance. Also, some of the mistakes seemed to be a mixture of the teacher's pronunciation, the learners' background, with the learners' background overdoing teacher's pronunciation. However, this teacher-induced error cannot be related to bad teaching. In fact, teachers themselves, as the literature has revealed, belong to the Francophone community, whose French has been shown to display several faults (Wamba \& Noumssi, 2003; Onguene Essono, 2012).

Figure 1 above showed that only Pattern IV was easy for the learners. This is certainly due to the fact that there were little accent variations as compared to other patterns. However, this was not the easiest as far as writing was concerned. This means that the influence of oral production on written production is not glaring with this pattern.

On the other hand, although Pattern III was troublesome in the oral form, the informants did not face major difficulties when putting it into writing. But, as mentioned earlier, this is an 'accidental' positive transfer, and their oral performance clearly reinforces this stance. It is accidentally positive in the sense that the learners did not conscious implement any rule to achieve that performance. It was their reluctance to use accents that resulted in that apparently good achievement. As for Patterns I and II, the presence of the silent vowel or the schwa was a breakthrough in this study. Actually, this phonological detail had a tremendous impact on vowel variation. The learners were found to have as much difficulty in the oral production as the written production of grammatical accents when this was involved. A comparative table of learners' performance upon teacher's reading and model readings revealed very interesting facts in that respect. This is summed up in the Table 6 below.

Table 6

Comparative learners' written performance in Pattern I

\begin{tabular}{lccccc}
\hline Total Students & \multicolumn{2}{c}{ Teacher Reading } & \multicolumn{2}{c}{ Model Reading } & \multirow{2}{*}{ Total } \\
\cline { 2 - 5 } & Passed & Failed & Passed & Failed & \\
\hline Number of students & 55 & 105 & 23 & 137 & 160 \\
Percentage & $34,37 \%$ & $65,63 \%$ & $14,37 \%$ & $85,63 \%$ & $100 \%$ \\
\hline
\end{tabular}

The table highlights the fact that, in Pattern I, the model reading induced many more mistakes on the part of the learners than did the teacher readings. This can be accounted for by the fact that teacher readings were closer to the local variety that corresponded to the mental model the learners had constructed as a referent to that physical shape. A word like 'Médecin' which was found to be consistent in the teacher readings and the local pronunciation $/$ medes $\tilde{\varepsilon} /$, was a real challenge to a learner when pronounced $/$ meds $\tilde{\varepsilon} /$ or $/$ meds $\tilde{\varepsilon} /$. This falls in line with the correlation established by Grainger \& Hannagan (2014) between the mental image of words and the way their phonetics are shaped. Therefore, it can be postulated that pronunciation $\mathrm{X}$ triggers spelling $\mathrm{Y}$. In cases where the pronunciation changes, the spelling is likely to differ, leading to the type of mistakes obtained with this pattern of grammatical accents. According to Grevisse \& Goose (2011), the presence of a silent ' $e$ ' in the penultimate syllable is due to the 'accentedness' of the vowel of the last syllable, as in the word 'appeler'. Each time the ultimate syllable features an accented vowel sound, the 'e' in the penultimate syllable is silent. This rule, which combines elements of phonology and orthography, can be significant in solving accent-related orthographic problems in nonnative settings. It is a rule that is generally breached in the local variety (as observed in the data and also impressionistically), so that when it was respected by the model reader, the learners potentially felt some 
embarrassment, since the phonetic shape that was provided to them did not match any known physical shape in their visual repertoire.

\section{Sociolinguistic foundations}

Linguistic features have been established in renowned literature as major classifying elements among different social, racial, and linguistic groups (Labov, 1966; Trudgill, 1974). However, the use of French grammatical accents by English-speaking learners of French in Cameroon, as displayed by the current work, points to the assimilation of one language group (let us call it group A) by another (let us call it Group B) in a contact situation, and where Group B was originally assimilated by another language group (let us call it Group C). These labels refer to Anglophone Cameroonians (Group A), Francophone Cameroonians (Group B), and Frenchmen (Group C). As a reminder, part of Cameroon was mandated to France by the League of Nations after WWI, while another part went to England. The French colonial masters imposed French as the language of education and administration (Mendo Ze, 1992) on its possession. Therefore, Cameroonians living in French Cameroon were assimilated. Today, decades after independence, many Anglophones are rejecting what they call the Francophone assimilation of Anglophones (Takam, 2003). Knowing that Francophone Cameroonians have developed some appropriative forms of French, the latest assimilated group (the Anglophones) has been exposed to a mediated form of the language that has already been transformed by the second generation of its users.

In fact, and this has not been highlighted in previous works, even the Cameroonian elite seems to speak a Cameroonian variety of French, at least to a certain extent. This can be illustrated by a number of neologisms invented by Cameroonians to stigmatise those who speak with a Parisian accent. Some of those expressions identified in Telep (2017) and also observed impressionistically include:

- Whitiser (Meaning: to speak like a Frenchman)

- Chirac, sors de ce corps! (Literally meaning that the person speaking has a Frenchman's spirit that speaks through him; Chirac, one former French president, epitomizes the Frenchman in this case)

The existence of such expressions to refer to those speaking with a Parisian accent simply reveals that the accent Cameroonians are versed with differs from the native accent. It also reveals the negative attitude people have towards those who want to affect when speaking the language. This attitude, although it has not been clearly linked to either people's poor performance or the attitude towards the former colonial power, potentially anticipates the accents used in the country.

Therefore, the English-speaking Cameroonian who learns French is exposed, right from the beginning, to a non-native accent. This can be illustrated both by their personal oral performance, which betrayed the quality of the language they are exposed to, and by the major oral errors made by the French teachers who read out the dictation to their students. The tendency to produce accented "e" when none was required was highlighted in their oral production as illustrated below.

Table 7

Major deviant forms associated with Pattern I

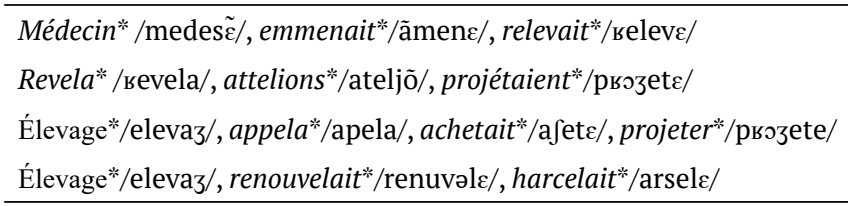

The analysis of the learners' performance correlates this use of accents by their teachers. This sociolinguistic environment therefore seems to determine what the language learners are exposed to. This language he or she is exposed to, in turn, influences the language he or she writes, as the analysis has shown. The problem is therefore not in French per se. There seems to be only a loose link between the mistakes made by the learners and the structure of the language itself. The problem lies in the quality of the input the learners are usually exposed to. This input later influences their written production. On the other hand, the first language of the learners surprisingly reduced the number of mistakes, especially when no physical accent was required. This means the mistakes made here are not to be blamed on the first language of the learners.

This language use may revive the issue of the purity of French. Although neither party seems to be wrong, it seems that the way French is spoken may have tremendous implications far beyond the appropriative use point raised by those for the development of a local form of French ( (Nzesse, 2008) and the purity of the language raised by the guardians of the norm (Mendo Ze, 1992). Actually, if one could establish the link between the proper use of a language and the written productions of learners, whitising (approximating standard French accent (Telep, 2017) or speaking with a Parisian accent could appear a necessity.

\section{Pedagogical implications}

Although this paper does not intend to solve the debate over the appropriative use of French in Cameroon, it clearly shows that the use of the correct phonological features of a language affects the spelling of that language, especially with a syllabary language 
like French. The problem arises in non-native settings where French is both a second and a foreign language. As a second language in Cameroon (to Francophone Cameroonians) it is said to have gone through a number of appropriative uses that have transformed it. This transformed French is then taught to those for whom French is a foreign language, namely Anglophone Cameroonians, by Francophone teachers. These teachers have already adopted a form of the language that is very much corrupt and which they teach to their Anglophone students. Their students are thus exposed to a non-native accent that affects their written language, as this paper has shown. Hence, a Parisian accent could definitely influence the mastery of some aspects of French orthography, especially those related to accents. Actually, the analysis above has established beyond a reasonable doubt that the pronunciation of certain words influences their writing and that French orthography is deeply rooted in the mastery of its phonology. There seems to be an apparent neglect for this aspect of literacy, in most works focusing on reading, and orthography as a major aspect of literacy (Bouma, 1971; Chanceaux \& Grainger, 2012).

Yet, phonological consciousness, which should not be confused with linguistic pretention or arrogance, may contribute to a certain extent to the mastery of such areas of French. This means that teachers of French should create this linguistic awareness in their learners that could ignite in the latter the development of mnemonic techniques in relation to those words. It can be foretold that a child who is taught that there is a strong correlation between the "accentedness" of the last vowel and the "unaccentedness" of the penultimate vowel would use oral clues to identify the appropriate grammatical accent. This will surely be incremental in the development of orthographical skills, although it will not solve all the learners' problems.

Furthermore, the consciousness of the role of accents in the doubling or not of consonants can help guide students during conscious reading. In fact, when one reads, the brain captures the picture of words that are being read, before the phonological shape of the word itself is produced. This may be because 'orthographic processing in humans makes use of a small part of a brain region (ventral occipital-temporal cortex) known to be involved in the identification of various kinds of visual objects' (Grainger \& Hannagan, 2014, p.13).

"Whitising" in this form shifts from the sociolinguistic sphere to the pedagogical one, mainly because it neither prevents the appropriate use of the language in former colonies, nor does it foster it. It is even more so because it can intrude into the intercultural knowledge of the learners and wipe out some of the prejudices linked to a certain form of
French, especially the one spoken by Africans living in France who are believed to affect it in order to highlight their French heritage and their success. The major challenge of this situation may reside in the fact that it could only be solved permanently after two generations, teachers as well as their learners having to be trained in an appropriate way, so that neither could later transfer these errors into the next generation. Actually, not only should learners be aware of these slight variations, but teachers also should be made to understand that their speech greatly influences the acquisition of some aspects of the language they teach. They should expose learners to correct input by reducing their own errors so the learners' errors could be significantly reduced.

\section{Conclusion}

This paper aimed at probing the potential link between spoken and written language in a multilingual setting. It specifically examined the influence of spoken French on the use of grammatical accents by Englishspeaking learners of French in Cameroon. It was hypothesised that the language used by those learners would be influenced by the quality of the input they are exposed to. The case revealed some interesting facts. Firstly, the French language those learners are exposed to is already "polluted", as shown by previous works as well as impressionistic observations and data collection. Then, this polluted language is transposed in the learners' written and spoken language. This shows that the problem is not the internal structure of the language per se that hampered the mastery of this aspect of the language. This sociolinguistic foundation to the errors English-speaking Cameroonians make in the use of grammatical accents in French announced the pedagogical stake of the purity of French. The work finally portended that the use of standard French could help curb the tide of the errors learners made in using grammatical accents. This study underscores the fact that the use of a Parisian accent is not just a luxurious choice, but a reasonable one.

\section{References}

Altapedia online. (2003). Countries A to Z: Cameroon. http://www.atlapedia.com. Accessed on October $11,2009$.

Bouma , H., \& Legein, C. P. (1971). Visual recognition of isolated lower-case letters. Vision Research, 11, 459-474.

Bullock, B. (2009). The French Language Initiative: 
French Language Advocacy Kit. American Association of Teachers of French (AATF).

Chanceaux, M., \& Grainger, J. (2012). Serial position effects in the identification of letters, digits, symbols, and shapes in peripheral vision. Acta Psychologica, 141, 149-158.

Corder, P. (1975). Error analysis and language. Oxford: Oxford University Press.

Corder, S. P. (1974). Error Analysis. In J. L. Allen, \& S. P. Corder, Techniques in Applied Linguistics. Oxford: Oxford University Press.

Dieu, M., \& R. Renaud. (1983). L'Atlas linguistique du Cameroun [The Linguistic atlas of Cameroon]. Paris: CERDOTOLA-Agence de coopération culturelle et technique.

Ferguson, C. A. (1975). Towards a characterisation of English foreigner talk. Anthropological Linguistics, 17, , 1-14.

Filipovic, R. (1972). Some problems in studying the English elements in the main European languages. Studia Anglica Posnaniensia, 4, 141-158.

Fosso. (1999). Créativité lexicale sur le campus universitaire de Yaoundé I: Etude du champ lexical de la sexualité [Lexical creativity on the Yaoundé I university campus: A study of the lexical field of sexuality]. Le français en Afrique noire, 13, 50-57.

Gass, S. M., \& Selinker, L. (2008). Second language acquisition: An introductory course, 3rd edition. Abingdon: Routledge.

Grainger, J., \& Hannagan, T. (2014). What is special about orhtographic processing? Written Language and Literacy, 17(2), 225-252.

Grevisse, M., \& Goose, A. (2011). Le Bon usage, 15ème édition [The Good usage]. Bruxelles: Editions de Boeck Université.

Grimes, B. (2000). The Ethnologue: The languages of the world, 14th edition. Texas: Summer Institute of Linguistics.

Hawkins, R., Towell, R., \& Bazergui, N. (1993). Universal Grammar and the acquisition of French verb movement by native speakers of English. SAGE Journals, Vol. 9, Issue 3, 189-233.

James, C. (1998). Error in language learning and use. New York: Addison Wesley Longman.

Jikong, S., \& Koenig, E. (1983). Language usage in Cameroon urban centres. In E. Koenig, E. Chia, \& J. Povey, A sociolinguistic profile of urban centers in Cameroon (pp. 55-77). Los Angeles: Cross Roads Press.

Kouega, J.-P. (2003). English in Francophone elementary grades in Cameroon. Language and Education, 17, 408-420.

Kouega, J.-P. (2007). The language situation in Cameroon. Current Issues in Language Planning (CILP), 8(1), 1-94.

Krashen, S. D. (1976). Formal and informal linguistic environments in language acquisition and language learning. TESOL Quarterly, 10(2), 5-16.

Labov, W. (1966). The Social stratification of English in New York City. Washington, DC: Centre for Applied Linguistics.

Lado, R. (1957). Linguistics across cultures: Applied linguistics for language teachers. Ann Arbor: Universityof Michigan Press.

Lewis, M. P. (2009). The Ethnologue: The languages of the world, 16th Edition. Dallas, Texas: SIL International.

Manessy, G. (1979). Créolisation et français régionaux [Creolisation and regional varieties of French]. In P. Wald, \& G. Manessy, Plurilinguisme: norme, situations, stratégies. Paris: L’Harmattan.

Mendo Ze, G. (1992). Une crise dans les crises: Le français en Afrique noire francophone [A crisis among crises: French in francophone subsaharan Africa]. Paris: ABC.

Ngoh, J. V. (1987). Cameroon, 1884-1945: A hundred years of history. Limbe: Navy Group Publication.

Nzesse, L. (2008). Le français en contexte plurilingue, le cas du Cameroun: appropriation, glottopolitique et perspectives [French in a purilingual context, the case of Cameroon: Identification, glottopolitics and perspectives] didactiques. Francofonia, 17, 302323.

Onguene Essono, L. M. (2012). Innovation morphosyntaxique en presse écrite francophone: analyse de quelques emplois de la préposition dans les médias camerounais [Francophone newspapers morphosyntactic innoavtion: Analysis of the use of some prepositions in Cameroonian media]. Le français en Afrique, $N^{\circ} 27,137-151$.

Orsenna, E. (2007). La Révolte des accents. Montréal: Stock.

Pollock, J.-Y. (1989). Verb movement, universal grammar, and the structure of IP. Linguistic Inquiry, 20(3), 365-424.

Scovel, T. (2001). Learning New Languages: A guide to second language acquisition. Massachusetts: Heinle $\&$ Heinle.

Selinker, L. (1972). Interlanguage. International Review of Applied Linguistics, 10(3), 209-31.

Takam, A. F. (2003). Bilinguisme officiel et promotion de la langue minoritatire en milieu scolaire: Le cas du Cameroon [Official bilingualism and the promotion of the minority language in education: The case of Cameroon]. Sudlangues, 7, 26-48.

Tarone, E. (1969). A selected annotated bibliography on social dialects, for teachers of speech and English, (Lab report series C / Washington) . Washington: Unknown binding.

Tarone, E. (1979). Interlanguage as chameleon. Language Learning 29(1), 181-191.

Telep, S. (2017). Speaking without an accent : ideologies about phonetic accommodation 
among Cameroonian immigrants in Paris. http://phonetiquedufle.canablog.com/archives 2013/09/23/28072866.html.

Trudgill, P. (1974). The Social differentiation of English in Norwich. Cambridge: Cambridge University Press.

Vinay, J.-P., \& Darbelnet, J. (1977). Stylistique comparée du français et de l'anglais [Comparative stylistics of French and English]. Paris: Marcel Didier.

Wamba, R., \& Noumssi, G. M. (2003). Le français au Cameroun contemporain: statuts, pratiques, problèmes sociolinguistiques [French in contemporary Cameroon: Statuses, practices, sociolinguistic problems]. Sudlangues, 2, 1-20.

White, L. (1989). The adjacency condition on case assignment: do L2 learners observe the subset principle? In S. Gass, \& J. Schachter, Linguistic perspectives on second language acquisition (pp. 134-158). Cambridge: Cambridge University Press.

Zang Zang, P. (1999). Le phonétisme du français camerounais [Cameroonian French phonetism]. In G. Mendo Ze, Le français langue africaine. Paris: Publisud. 


\section{Appendix}

\section{Dictation 1}

Apres le dîné organisé par le médecin à l'occasion du renouvèlement des vœux de fidélité à l'endroit de son épouse, il révéla à l'assistance que le scénario de cette scène si réussie était grâce à sa femme. Après ce discours, nous nous attelions à alléger la tâche du nettoyage aux domestiques qui emmenaient tour à tour la vaisselle à la cuisine. Ce geste du couple relevait d'une confiance totale en nous. Ceux d'entre nous qui projetaient de vivre le célibat encore longtemps ont descellé les portes de l'amour.

\section{Dictation 2}

Un samedi soir où nous étions tous crevés de fatigue, après la longue journée de pèlerinage et de jeûne, nous dégustions des cerises quand la secrétaire appela pour nous informer d'un incendie à l'usine. A la grève de la journée, les employés avaient décidé de mettre le feu à l'usine. Ce geste semait ainsi la haine entre tous, un péché très dangereux. Les urgences dépêchaient les blessés à l'hôpital et emmenaient les morts à la morgue. C'est ainsi que s'acheva cette journée de soulèvement dans la plus grande des tristesses.

\section{Dictation 3}

Mon papa, grâce à l'appui de son frère géomètre, investit dans l'élevage du gros et du petit bétail. Il appela du village cinq autres cousins pour lui alléger la tache. Chaque semaine, il achetait de nouveaux produits, renouvelait ses techniques de travail afin de rendre son élevage plus rentable. Pour le bon suivi des animaux, il harcelait ses cousins en ces paroles : « on élève un animal tel un enfant qu'on aime ; on éloigne de lui tout ce qui achèverait ou empièterait sur sa croissance ». A l'âge de 40 ans il dit alors à son frère : "tout ce temps je me suis consacré à mes animaux et j'ai formé des personnes capables d'en prendre soin. Il est temps pour moi de projeter autre chose, je ne ferai pas la géométrie mais plutôt la poésie. » Aussitôt, je compris pourquoi malgré les occupations de mon papa il restait tant accroché aux vieux poèmes d'Hugo et de Shakespeare.

\section{Dictation 4}

Des amis, j'en ai eu. Des scènes, j'en ai vécu. Des expériences, j'en ai aussi vécues; mais la plus grande fut la disparition de grand-père. Lui, c'était un vrai, grand ami, toujours fidèle. Tout le monde pèche ; mais ses péchés, étaient-ils plus grands que les nôtres pour qu'il s'en aille si tôt ? Était-il tout simplement vieux pour continuer à vivre ? Si seulement j'avais eu assez de force, je l'eus soulevé lorsqu'il tomba de sa chaise roulante. Même la médecine n'a pu lui redonner vie. Il y' aurait certainement eu quelque chose qui allègerait sa peine. Hélas ! Il n'est plus. Je me souviens encore de ses paroles « fais toujours le bien ». C'était un vrai semeur de joie et d'amour. Mon cœur est en grève de joie depuis qu'il est parti. On dirait que le vent de la mort a tout dévasté en moi. Comme un pèlerin je me promets de faire renaitre en moi l'amour et je le sèmerai en chacun de mes frères pour le bien de mon grand-père 